 \\ International Journal of Social Sciences and Management
}

\section{A Rapid Publishing Journal}

ISSN 2091-2986

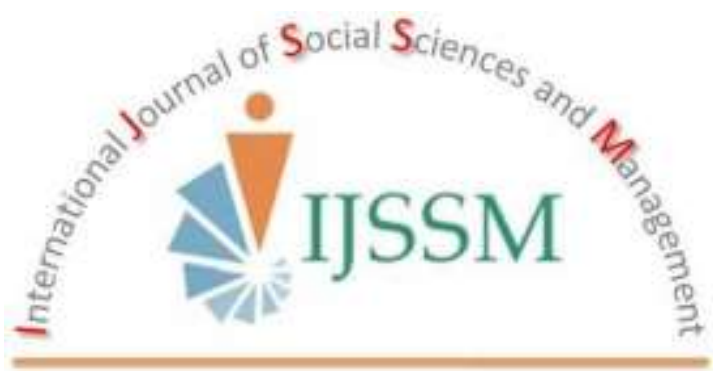

\section{Indexing and Abstracting}

CrossRef, Google Scholar, International Society of Universal Research in Sciences (EyeSource), Journal TOCs, New Jour, Scientific Indexing Services, InfoBase Index, Open Academic Journals Index (OAJI), Scholarsteer, Jour Informatics, Directory of Research Journals Indexing (DRJI), International Society for Research Activity (ISRA): Journal Impact Factor (JIF), Simon Fraser University Library, etc.

Vol-2(1) July, 2015

SEM-Biotech

Publishing
Impact factor ${ }^{*}: \mathbf{3 . 3 8 9}$ 
Research Article

\title{
TESTING THE GREATEST MANAGEMENT PRINCIPLE (GMP) FOR EFFECTIVE TRANSFORMATION OF THE SUB-SAHARA AFRICA-AN EMPIRICAL EVIDENCE FROM NIGERIA
}

\author{
Agbionu Clementina Uchenna ${ }^{1 *}$, Florence Agbodike ${ }^{2}$ and Ojiagu. N. ${ }^{3}$ \\ ${ }^{1}$ Department of Business Administration, Nnamdi Azikiwe University, Awka, Nigeria \\ ${ }^{2}$ Department of Public Administration, Nnamdi Azikiwe University, Awka, Nigeria. \\ ${ }^{3}$ Department of Cooperative Economics and Management, Nnamdi Azikiwe University, Awka, Nigeria. \\ ${ }^{1 *}$ Corresponding author's email: uctinagbionu@gmail.com
}

\begin{abstract}
The poor recognition of the critical role human beings play in the realization of organizational goals has led to consistent poor performance of organizations especially in the Sub-Sahara Africa. No meaningful transformation can be achieved if the human element in production process is toiled with, used and abandoned. This paper empirically investigated the claim by Michael LeBoeuf in his Greatest Management Principle Model in the world that "what gets rewarded gets done." 87 respondents participated in the survey of the 13 ministries in Anambra State Civil Service. The instrument was adequately validated and its reliability duely established. The hypothesis of the study was tested using Z-Statistics to discover the difference between two means of the main variables of the study. The results showed that the cumulative mean of positive behaviours rewarded is 3.80 while the negative behaviours rewarded is 2.44 . This made the null hypothesis to be rejected while the alternative was accepted. The significance of the difference was authenticated using the values of the standard errors. The findings of the study is that when employers reward positive behaviours in relation to the objectives of the organization, positive response would come from the employees. This was found to increase the performance of the employees. The study recommended among other things that the rewards employers give to employees must flow out of the objectives of the organization.
\end{abstract}

Keywords: Testing; Greatest Management Principle; Effective Transformation; sub-Sahara Africa.

\section{Introduction}

That human beings are indispensable in the accomplishment of any goal in life is indisputable. That the effective management of human beings culminates into the effective management of other resources in life is truism. That human beings can make or mar any situation no matter how difficult such situation presents itself is obvious. These may probably have been why Wilson (1996) stated as quoted by Agbionu (2006) that "the human being is the yardstick of everything". Banjoko (1996 and 2006) supported the above view by stating that "if you dig deep into any problem, you would get people." Many organizations do not realize this fact and the consequences on them have been very expensive. The root causes of this lapse could easily be attributed to poor management of organizational resources by those that supposed to do so. The remote reason behind this may be attributed to the fact that management is practiced by everybody but only experts in management understand the rudiments of management for effective and efficient management of organizational resources.
Management is pervasive, encompassing and universal. It cuts across every facet of human endeavor. Almost everybody - illiterate and literate claim to be seriously involved in the practice of management. From their own uniformed point of view, they may be right but from the experts' theoretical and practical point of view, they may be doing more harm to management and its immediate and remote environments than good. These probably had been the reason why countries both under-developed and developing remain in their poor positions after many years of existence and independence. In these developing countries, management has not been practiced the way it is supposed to be practiced. A typical example is Nigeria because many sources including National Planning Committee (2005) blame the chronic problem of underdevelopment and its attendance consequences on poor management of resources because according to NPC (2005) Nigeria is greatly endowed with all the resources to be selfreliant.

The ebb and flow of the concept of management from a position of obscurity to that of relevance and highly 
embraced within the organizational contexts of the modern society has been one of the more remarkable events of the twentieth century history as Agbionu, Emejulu and Adigwe (2013) put it. Management since then has continued to grow at a very alarming rate. Some statistical evidence has shown that in Britain alone, there were 2.75 million people engaged in management with 90,000 persons entering the occupation each year. Similarly, census data from the United States have shown that there were more than 500,000 students in basic courses in management. The report continued that in Nigeria, the story is not different as there are over 5 million people working in managerial capacities in the length and breadth of the country. The concentration acquiring management knowledge and skills is also supported by the fact that over $60 \%$ of admissions into higher institutions in the country are for management related courses while not less than $90 \%$ of postgraduate admissions are also for management and management related course.

On Measuring the Quality of Life and property President Obasanjo Stated that we thereby tend to overlook that the main goal of life is to ensure survival and to enable everyone to realize his full potential for well-being, fulfillment, and accomplishment in happiness, joy, love and contentment (Obasanjo, 2003). National income figures neither reveal the real beneficiaries nor the composition of that income. This has been the experience in Nigeria not because the resources to realize this dream are not there but according to NPC (2005), the greater hindrance to progress in Nigeria has been the boom-and-bust mode of economic management encouraged by the dominance of Oil in the economy. NPC (2005) also noted that despite great natural wealth, Nigeria is poor and social development is limited. If the present trends continue as NPC (2005) puts it, the country is not likely to meet the Millennium Development Goals (MDGS) and this is applicable to many countries in the Sub-Sahara Africa.

Though the above record shows that Nigeria is doing well economically, but the same report stated that Nigerian economy faces many challenges which the Transformation Agenda is designed to address. These challenges according Agbionu and Agbionu (2013) include: Insufficient Jobs and Poverty, Dependency on Oil Exports, High Food Importation Food Insecurity, Housing Deficit, and Infrastructure in Poor State, High Inflation, Falling Reserves, High recurrent Expenditure, and Rising Domestic Debt. With very promising elements of the national economy, one would expect that the citizens of this country would be experiencing low level of poverty but the challenges facing the economy are the indicators that all is not really well with Nigeria and her citizens. The immediate blame of this apparent disparity is poor management. Supporting this position, President Goodluck Jonathan stated in his 2014 Democracy speech that Nigeria is not poor but the problem of Excess Crude Account (ECA) rise from about $\$ 84$ billion in May 2011 to around $\$ 9$ billion at the end of 2012, but now about $\$ 6$ billion in May, 2013, ECA now helping us since Oil production has fallen from the projected 2.53 million bpd to be between 2.1-2.2 million bpd. Cost of Government is reducing with recurrent expenditure dropping from $74.4 \%$ of total budget in 2011 to $68.7 \%$ in 2013, Government borrowing declined with annual borrowing fallen from \#852 billion in 2011 to \#588 billion in 2013, National Debt is low with a Debt to GDP in Nigeria - $21 \%$. South Africa $-42.7 \%$, SSA - 34.2\%, USA $106 \%$, Japan $-225 \%$, UK $-90 \%$, Waiver and Tariff policies have changed from government focusing on sectorial waivers rather than individual e.g agriculture, power, aircraft spare parts, solid minerals at zero duty, Waiver and Tariff policies have changed - Imports are down (textiles, plastic and rubber, paper making material), and exports are up (plastic and rubber, vegetable product, prepared food stuff and beverages), Non-oil exports have increased from $91 \%$ of total exports in 2008 to $31 \%$ in 2012 . Oil exports are now $69 \%$ of total exports, compared to $91 \%$ in 2008 (FGN, 2005).

These figures point to the fact that the Nigerian government is actually doing well but the effect of her performance needs to be felt significantly among the rural dwellers. A casual observer may be tempted to ask why the probe into the actual meaning of management and why it seems that management has not fully lived up to its expectation in the Sub Saharan Africa with greater concern in Nigeria. Though records from Performance Management Records (PMR) (2014) have it that the GDP growth in 2013 in Nigeria is expected at $6.5 \%$ (NBS) or $7.2 \%$ (IMF), the Exchange Rate is stable with a Dollar exchange rate between $\$ 155$ and $\$ 160$ over the last two years, Rate of Inflation is coming down at a rate of $9.1 \%$ from $12.4 \%$ in May 2011, External Reserves are rising from $\$ 32.08$ billion in May, 2011 to $\$ 48.4$ billion in May, 2013, but the average rural dweller in many villages who are at the receiving end has a very sour story to tell.

The Greatest Management Principle (GMP) model is a work and worker oriented model for dealing conclusively with organizational challenges and problems. It is specifically aimed at getting positive results. Management has remained one of the most abused areas of specialization. Almost everybody seems to be involved in the act of management directly or indirectly without actually knowing really and understanding specifically what management is, its involvements and purposes. These erroneous conceptions of the subject of management has defiled every strategy for solution by the "so called" managers and pitiable managers.

Based on the above, the study empirically tested the Greatest Management Principle (GMP) model to ascertain its effectiveness in the transformation plan of the Sub- 
Sahara Africa. In view of the above, the study hypothesized that GMP model would not have any significant influence in the motivation of employees for greater performance in organizations in Sub Sahara Africa for effective and efficient transformation.

\section{Literature Review}

\section{Greatest Management Principle (GMP) in the World in Perspective}

Greatly worried by the performance of U.S firms, Micheal LeBouef in 1989 went into a comprehensive research to find out why many U.S firms have not been performing the way they were supposed to perform. He wanted to specifically find out what was wrong with many U.S firms in order to design strategies for self-improvement and better business practices. The text began with a quiz which stated "Does this sound like where you work?" The answer which many readers were expected to give to this question was yes. This is because the question dealt with the basic problems inherent in all human organizations the - gap between ideals and practice. When it was established that many U.S organizations experienced the same thing, and would all benefit from the Greatest Management Principle (GMP), the book presented the basics which include the principle itself which was stated and expatiated. The second part of the model dealt with the strategies. For this aspect of the principle, Micheal LeBoeuf, a professor of management at the University of New Orleans, addressed the problems posed by the question he asked. In addition, he presented a step-by-step method for dealing with each problem. For instance, he presented an exercise on practical ways to reward risk-taking instead of risk-avoiding and quality work instead of fast work, etc.

At the end of the principle in the third part, he presented ten "Action plans" that exposed the managers on how to reward. He also presented specific exercises that were supposed to help one find the answer to the three crucial questions such as "Which behaviors do I want?, "How will I recognize such behavior?". The sample plans he presented discussed practical steps on how to manage subordinates and, if appropriate, one's boss. At the end of his presentation with a brief summary of the GMP and a request for the reader's favorite way to solve problems with the GMP.

A critical appraisal of the GMP principle presented by Bugle (2013) noted by questioning whether the chief rewards for which employees work always correspond with the reward system that management usually put in place? He asserted that it does not always follow. He maintained that though management may be rewarding glibness and self-promotion for instance, there will always be some employees who will do important tasks well sorely for their own personal satisfaction. This according to him made
LeBoeuf's GMP no less valid. However, he added that because these few self-motirated people are never enough to ensure a company's success, GMP should be designed as a part of every manager's philosophy.

A good question a critical management philosopher would use to challenge LeBoeuf's principles is "What exactly connotes quality management? to either approve or disapprove of the claim of LeBoeuf that the principle is the greatest principle in management. According to Bage (2012), "quality management principle" can be summed up as the rule or philosophy of which executives of an organization motivated subordinates to move towards a desired objective. This definition by its own merit can be used to affirm the claim of Micheal LeBoeuf. LeBoeuf maintained that the best way to manage organizations effectively is to set desired objectives and motivate employees who make things happen rightly to achieve the objective. Agreeing completely with the propositions and discoveries of Micheal Leboeuf, Berge (1972) noted that there are considered to be eight quality management principles that effective leaders are prone to employ. These include; leadership, customer focus, involvement of people, process approach, system approach to management, continual improvement, factual approach to decision and mutually...." These strategies above are used to achieve the objectives of an organization. If this is the case, it then implies that the GMP is the 'mother' of all the above strategies. This is so because GMP as LeBoeuf (2009) indicated was used to achieve the goals of organization. Still in agreement with the propositions of LeBoeuf (2009), Buffett on the importance of rewarding the right behavior stated that he does not consider themselves to be richer or poorer based on what the stock does. "We do feel richer or poorer based on what the business does." "We look at the business as to how much we're worth, not the stock price because the stock price doesn't mean a thing to us", he concluded.

Theoretically, the GMP model is underpinned by the B.F. Skinner's Reinforcement Theory. For instance, when an employee performs better in an assignment, he is rewarded for doing so. When this employer keeps on getting rewarded for increase in performance (positive behaviour) in form of incentives (the results), other employees will emulate him and consequently all the employees would follow suit. In the work place, employees can be rewarded in line with the desires and aspirations of managers in order for the employees to emit positive response towards achieving the goals of the organizations. For instance, managers and other sales men are given new business goals to achieve, but their pay structure provides the same commission for new business as the commission they receive from performing their duties. Finding new emits and generating new revenue is incrementally harder than serving current customers (or contributors) who already like as and see value in doing 
business with our company or organizations. So without an incentive designed specifically for acquiring new customers, new business goals may be achieved, but probably won't.

LeBoeuf (2009) presented ten best ways to reward behavior in line with the result of his research as follows: money, recognition time - off, a piece of the action, offering favorite work, advancement, freedom, opportunity for personal growth, fun and prizes (making people feel like winners). The key here according to LeBoeuf is not that reward is important but knowing what to reward is the key. He also stressed from his study that organizations have to have a strategy and a system in place that allows them to monitor and measure activities.

In conclusion, LeBoeuf stated that for organizations to be successful, they have to adopt these new strategies which are:

1. Reward Solid solutions instead of Quick fixes

2. Reward Risk Taking instead of Risk Avoiding.

3. Reward Applied Creativity instead of Mindless Conformity. Have our staff members focused on what is important, and our companies and organization on the right track?

4. Reward Decisive Action instead of Paralysis by Analysis

5. Reward Smart Work instead of Busy work

6. Reward Simplification instead of Needless Complication

7. Reward Quietly Effective Behavior instead of Squeaking Joints

8. Reward Quality work instead of Fast work

9. Reward loyalty instead of Turnover

10. Reward Working Together instead of Working Against

By understanding how "We reward", having a system in place that allows us to monitor and measure activity, following a thorough full and proven strategy for achieving desired results, and constantly asking ourselves "What's being rewarded"?, we will keep positive ones by ourselves and negative ones by him.

\section{Materials and Methods}

This study is a theory -testing study which was used to practically test the GMP in Nigerian environment. The study is a survey of all categories of workers in the Anambra State Civil Service concentrating on all the employees in the 13 ministries in the Civil Service who were selected randomly from the 13 ministries. A total of 100 employees participated in the survey, but 87 questionnaires were returned. There was one employee below 20 years, 31 employees were between the age range of 20-30 years, 46 were between the age range of 30-40 years while 9 employees were in the age range of 50 years and above. Out of the 87 employees, 28 were males while 59 were females.

The means and the standard deviation were the descriptive statistics employed for the study. The grand means for the positive behaviors showed a value of 3.80 which fell within the accepted region while the grand means for the negative behavior rewarded showed a value of 2.44 which was below the acceptance region and therefore was rejected. The standard deviation of .54067 was recorded for the positive behavior while a standard deviation value of 69295 was also recorded for the negative behaviors rewarded.

Employees with secondary school certificate were 14 in number, 10 had NCE/OND, 56 had HND/B.Sc, 7 had MBA and related certificates. The employees below 5 years of experience were 39, 15 had between 5 -10 years of experience while 33 had between 10-15 years of experience. The major constructs of the study - reward and effectiveness were measured adequately. While reward was measured using the positive rewards as advocated by LeBeouf (2009), employees' effectiveness was measured from their performance from the reward they receive in the organizations. Content, face and construct validities were ensured while a test re-test reliability using Probable Error method showed a coefficient of correlation value of 0.82 which was judged adequate for the study. Bio data of Respondents is shown in Table 1.

Table 1: Bio data of Respondents

\begin{tabular}{|l|l|r|r|r|r|}
\hline \multicolumn{2}{|c|}{} & \multicolumn{2}{|c|}{ Age bracket } \\
\hline \multirow{4}{*}{ Valid } & Frequency & Percent & Valid Percent & \multicolumn{1}{c|}{$\begin{array}{c}\text { Cumulative } \\
\text { Percent }\end{array}$} \\
\cline { 2 - 6 } & Below 20 years & 1 & 1.1 & 1.1 & 1.1 \\
\cline { 2 - 6 } & Between20-30 years & 31 & 35.6 & 35.6 & 36.8 \\
\cline { 2 - 7 } & Between30-40 years & 46 & & 52.9 & 89.7 \\
\cline { 2 - 7 } & 50 and above & 9 & 10.3 & 10.3 & 100.0 \\
\hline & Total & 87 & 100.0 & 100.0 & \\
\hline
\end{tabular}


A.C. Uchenna.et al. (2015) Int. J. Soc. Sci. Manage. Vol-2, issue-3: 236-243

\begin{tabular}{|c|c|c|c|c|c|}
\hline \multicolumn{6}{|c|}{ Sex } \\
\hline & & Frequency & Percent & Valid Percent & Cumulative Percent \\
\hline \multirow[t]{3}{*}{ Valid } & male & 28 & 32.2 & 32.2 & 32.2 \\
\hline & female & 59 & 67.8 & 67.8 & 1000 \\
\hline & Total & 87 & 100.0 & 1000 & \\
\hline
\end{tabular}

\begin{tabular}{|c|c|c|c|c|c|}
\hline \multicolumn{6}{|c|}{ Edu Qualification } \\
\hline & & Frequency & Percent & Valid Percent & $\begin{array}{c}\text { Cumulative } \\
\text { Percent }\end{array}$ \\
\hline \multirow[t]{5}{*}{ Valid } & SSCIGCE & 14 & 16.1 & 16.1 & 16.1 \\
\hline & NCE/OND & 10 & 11.5 & 11.5 & 276 \\
\hline & HND/B SC & 56 & 64.4 & 644 & 920 \\
\hline & MBAMMPAMM SCIMED & 7 & 8.0 & 80 & 1000 \\
\hline & Total & 87 & 100.0 & 100.0 & \\
\hline
\end{tabular}

\begin{tabular}{|c|c|c|c|c|c|}
\hline \multicolumn{6}{|c|}{ Job experience } \\
\hline & & Frequency & Percent & Vatid Percent: & $\begin{array}{c}\text { Cumulative } \\
\text { Percen }\end{array}$ \\
\hline \multirow[t]{4}{*}{ Vaild } & Below 5yrs & 39 & 44.8 & 44.8 & 448 \\
\hline & Between 5-10yrs & ${ }^{4} 15$ & 172 & 172 & 62.1 \\
\hline & Between 10.15 yrs & 33 & 379 & 37.9 & 100.0 \\
\hline & Total & 87 & 100.0 & 100.0 & \\
\hline
\end{tabular}

\begin{tabular}{|l|l|r|r|r|r|}
\hline \multicolumn{2}{|c|}{} & Age brackot & \multicolumn{1}{|c|}{$\begin{array}{c}\text { Cumulative } \\
\text { Percent }\end{array}$} \\
\hline \multirow{3}{*}{ Valid } & Below 20 years & 1 & 1.1 & 1.1 & 1.1 \\
\cline { 2 - 6 } & Between20-30 years & 31 & 35.6 & 35.6 & 38.8 \\
\hline & Between30-40 years & 46 & & 52.9 & 89.7 \\
\hline & 50 and above & 9 & 10.3 & 10.3 & 100.0 \\
\hline & Total & 87 & 100.0 & 100.0 & \\
\hline
\end{tabular}

\begin{tabular}{|c|c|c|c|c|c|}
\hline \multicolumn{6}{|c|}{ Sex } \\
\hline & & Frequency & Percent & Valid Percent & Cumulative Percent \\
\hline \multirow[t]{3}{*}{ Valid } & male & 28 & 322 & 32.2 & 32.2 \\
\hline & female & 59 & 678 & 67.8 & 1000 \\
\hline & Tolal & 87 & 1000 & 100.0 & \\
\hline
\end{tabular}

\begin{tabular}{|c|c|c|c|c|c|}
\hline \multicolumn{6}{|c|}{ Edu Qualification } \\
\hline & & Frequency & Percent & Valid Percent & $\begin{array}{l}\text { Cumulative } \\
\text { Percent }\end{array}$ \\
\hline \multirow[t]{5}{*}{ Valid } & SSCIGCE & 14 & 16.1 & 161 & 16.1 \\
\hline & NCE/OND & 10 & 11.5 & 11.5 & 276 \\
\hline & HND/B SC & 56 & 64.4 & 644 & 920 \\
\hline & MBAMMPAMM SCIMEO & 7 & 8.0 & 8.0 & 100.0 \\
\hline & Total & 87 & 100.0 & 100.0 & \\
\hline
\end{tabular}

\begin{tabular}{|c|c|c|c|c|c|}
\hline \multicolumn{6}{|c|}{ Job experience } \\
\hline & & Frequency & Percent & Valid Percent & $\begin{array}{c}\text { Cumulative } \\
\text { Percent }\end{array}$ \\
\hline \multirow[t]{4}{*}{ Valid } & Below 5yrs & 39 & 448 & 44.8 & 448 \\
\hline & Between 5-10yrs & 15 & 172 & 172 & 621 \\
\hline & Between $10-15$ yrs & 33 & 37.9 & 379 & 1000 \\
\hline & Total & 87 & 100.0 & 1000 & \\
\hline
\end{tabular}


Table 2: Behaviour to Reward and Reward System and Employees Job Satisfaction

\begin{tabular}{|c|c|c|c|c|c|}
\hline \multicolumn{6}{|c|}{ Descriptive Statistics } \\
\hline & N & Minimum & Maximum & Mean & Std. Devizion \\
\hline Riwd longrun decisn & 87 & 100 & 5.00 & 37701 & 1.23810 \\
\hline Riwo-Cakenisk & B7 & 1.00 & 5.00 & 3.4023 & 1.21483 \\
\hline Rewe-solitude & 87 & 1.00 & 500 & 3.1954 & 1.14971 \\
\hline Rews-vital sesues & 37 & 100 & 500 & 3,9655 & 98178 \\
\hline Rind-short efforts & 87 & 100 & 500 & 29080 & 1.19721 \\
\hline Find-simplifers & 87 & 1.00 & 5.00 & 38968 & 1,02335 \\
\hline Piwd-reliable people & B7 & 2.00 & 5.00 & 44135 & 82901 \\
\hline Riwd-standards & 87 & 1.00 & 5.60 & 4.1034 & 91543 \\
\hline Rwd-loyalty & 87 & 1.00 & 500 & 4.1264 & 89667 \\
\hline Rend-team spert & Bi & 100 & 500 & 41954 & $105 / 34$ \\
\hline Riwd Sys short goals & 87 & 100 & 500 & 3.2969 & 1.21152 \\
\hline Fied-Sys aroid risk & 87 & 100 & 3.00 & 26607 & $13525 \mathrm{~T}$ \\
\hline Fiwd Sys-ingid rules & 87 & 100 & 5.00 & 28500 & 1.29874 \\
\hline Riwd Sys-distract gosis & 87 & 100 & 5.00 & 2.1034 & 1.16174 \\
\hline Find Sys-boc of noses & 87 & 100 & 5.00 & 17586 & 107796 \\
\hline Awd Sys-complicate issues & 87 & 1.00 & 5.00 & 13736 & 104390 \\
\hline Pwd Sys-secks atlentn & 87 & 100 & 500 & 17831 & $1035 s s$ \\
\hline Riwd Sys tast goals & 87 & 100 & 500 & 30000 & 115134 \\
\hline Rwo Sys-new encioyes & 87 & 1.00 & 5.00 & 2.4023 & 1.28000 \\
\hline Ruwd Sys-ndividual activity & 87 & 100 & 500 & 27011 & 1.31296 \\
\hline Vald N (istaise) & 87 & & & & \\
\hline
\end{tabular}

\begin{tabular}{|l|r|r|r|r|r|}
\hline & N & Mescriptive Statistics & \\
\hline GMimum & Naximumi & Mesn & \multicolumn{1}{|c|}{ Std Devis/on } \\
\hline Vatid N (listwise) & 87 & 221 & 474 & 32855 & 49773 \\
\hline
\end{tabular}

\begin{tabular}{|c|c|c|c|c|c|}
\hline & N & Minimum & Maximum & Mean & Sld, Deviation \\
\hline Rwd-longrun decian & 87 & 1.00 & 5.00 & 3.7701 & 1.23610 \\
\hline Rwd-Caic risk & 87 & 1.00 & 5.00 & 3.4023 & 1.21483 \\
\hline Fiwd-solitude & 87 & 1.00 & 5.00 & 3.1254 & 1.14971 \\
\hline Riwd-vital issues & 87 & 1.00 & 5.00 & 3.9655 & .98179 \\
\hline Rind-short efforts & 87 & 1.00 & 5.00 & 2.5000 & 1.19721 \\
\hline Rav-simpiners & 67 & 1.00 & 5.00 & 3.8986 & 102338 \\
\hline Rind-reiable pecple & 87 & 2.00 & 5.00 & 4.4138 & .82901 \\
\hline Riwd-standards & 87 & 1.00 & 5.00 & 4.1034 & 91543 \\
\hline Rivd-loyalty & 87 & 1.00 & 5.00 & 4.1264 & .89967 \\
\hline Riwd-team spint & 87 & 1.00 & 8.00 & 4.1954 & 1.08734 \\
\hline Vaid N (lastwise) & 87 & & & & \\
\hline
\end{tabular}

Negative Behaviours Rewarded

\begin{tabular}{|c|c|c|c|c|c|}
\hline & & & & Mean & Std. Deviation \\
\hline Riwd Sys-short goals & 87 & 1.00 & 5.00 & 3.2989 & 1.21152 \\
\hline Rend-5ys-awoid rask & 87 & 1.00 & 5.00 & 2.6687 & 1,35257 \\
\hline Rend Syrt-tigid nules & 87 & 1.00 & 5.00 & 2.8508 & 1.28874 \\
\hline Rwd Sys-distract goais & 87 & 1.00 & 500 & 2.1034 & 1.16174 \\
\hline Riwd Sys-lot of noise & 87 & 1.00 & 500 & 1.7586 & 1.07796 \\
\hline Riwd Sys-complcate issues & 87 & 1.00 & 500 & 1.8736 & 1.04330 \\
\hline Riwd Sys-seeks attentn & 87 & 1.00 & 5.00 & 1,7931 & 1.03585 \\
\hline Fiwd Sys-tast gools & 87 & 1.00 & 5.00 & 3.0000 & 1.15134 \\
\hline Fiwd Sys-new employee & 87 & 1,00 & 5.00 & 2.4023 & 1.28008 \\
\hline Rwd Sys-indwidual activiny & 87 & 1.00 & 5.00 & 2.7011 & 1,31286 \\
\hline Vald N (listwise) & 87 & & & & \\
\hline
\end{tabular}

Grand Mean -Positive Behaviours Rewarded and Negative Behaviours Rewarded

\begin{tabular}{|l|r|r|r|r|r|}
\hline & \multicolumn{1}{|c|}{ Descriptive Statistios } \\
\hline OM1 & Minimum & Maximum & Megn & Sld. Deviation \\
GM2 & 87 & 1.80 & 4.80 & 3.7977 & 56067 \\
Vaid N (listwise) & 87 & 1.30 & 4.50 & 2.4448 & 69295 \\
\hline
\end{tabular}




\section{Results and Discussion}

SPSS version 20 was used to test the hypothesis raised by the study and the results of the test of hypothesis and analysis of data were attached herein. The present study earlier hypothesized that the GMP principle would not have any significant influence in the motivation of employees in Anambra State Civil Service for greater performance. The hypothesis was tested using the Z-Statistic since the sample size was more than 30 otherwise the student t-statistic would have been used. To achieve this, the difference between two means method was adopted and the results showed that the mean for positive behaviors rewarded was higher than the mean for the negative behaviors rewarded. This implies that the positive behaviors rewarded had higher influence on the employees than the negative behaviors. A test of the significance using Z-test was confirmed from the values of the standard deviations. The negative behaviors rewarded deviated more from the normal with a value of .69295 more than the positive behavior which recorded a standard deviation value of .54067. Since the deviations from the standard approved statistically is higher in the negative behaviors, it then shows that employees value the positive behaviors rewarded more than the negative behaviors. As a result of this the rewards that had a higher influence in them influenced their performance more than the rewards that had less influence on them.

In line with the propositions of Michael LeBoeuf in his principle, "what gets rewarded gets done", the results above confirmed that knowing what to reward by managers is very important. Managers of organizations must be conscious of this and reward the employees using the reward they value at any particular time, otherwise giving reward to employees for the sake of it would amount to efforts in futility.

Though the above is the case but an old management theory which had stood the test of time states that employees would want to do what they want to do irrespective of how they are being influenced. In this theory, Lawler (1971) encouraged managers of organizations to strive hard to make sure that they use all avenues in their position to manipulate employees positively to their side. Mcgregor in his own theory $\mathrm{X}$ and $\mathrm{Y}$ insisted that human beings need to be manipulated to get the best out of them. Though very rigid, unpredictable and complex, human beings if properly rewarded and rewarding the right behaviour helps the rewarder to achieve his target. What the employer rewards according to LeBoeuf flows from what he wants to achieve and what he wants to achieve comes from the main mission of the organization. When the employees are rewarded rightly, they will definitely perform better. This also confirms Frederick Herzbergs motivation and hygiene theory He proposed when employees are rewarded in line with needs and that of the organization, they will be satisfied with the performance of their job and this satisfaction increases their productivity.

Though one may be tempted to criticize LeBoeuf for being employer or work-centred without considering other variables such as the values employees place on the rewards they receive that will also influence the effectiveness of the performance of the employees. This view agrees with what Maslow proposed when he stipulated the fact that the different employees are motivated at different times by different types of reward. Maslow emphasized that when employees are adequately rewarded at the level of motivation they operate they would perform better hammering on the personal values of reward to employees but LeBeouf insisted that reward is very effective and efficient when it flows from what the rewarder wants out of the objectives of the organization instead of the values of reward to employees irrespective of the requirements of the organization.

\section{Conclusion}

The study empirically investigated the claims by Michael LeBoeuf (2009) after several months of intensive research on the poor performance of U.S Organizations. He toiled night and day, made contacts, interviews, observed situations, monitored events and physically conducted surveys to unravel the reasons behind the poor performance of U.S. Organizations. The results from his study showed that many US organizations were not doing the right things especially in the areas of reward. He also observed that many US organizations have abandoned the basics, the fundamentals and the backbones for which successful organizations are made. They practically rewarded wrong behaviors which were in contrast to the goals of the organizations. Since rewards attract the repetition of behaviors rewarded (Agbionu, 2014), employees in US, Organizations kept on repeating the negative behaviors, their employers were inadvertently rewarding. This lasted for many years and consequently affected drastically the performance of the organizations.

The present study replicated the original study by applying the GMP in the public sector of Nigeria using Anambra State Civil Service as a study.

The results revealed that the employees of the Civil Service were greatly influenced by the rewarding of positive behaviors more than the negative behaviors. This implies that there is a significant relationship between positive rewards employees receive with their effectiveness (Agbionu, 2008). In other words, the effectiveness of the employees in the performance of their duties would be greatly influenced by the positive rewards employees receive. 
Any meaningful transformation of the sub-sahara African must be hinged on the roles human beings as the most important factor of production perform in organizations (Agbionu, 2013). These roles which will add up to the total productivity of organizations for survival, success and sustainability (SSS) of organizations must be effectively performed by the employees. This study has established empirically that when employers reward what they want, the employees would be more effective in the performance of their duties.

\section{Recommendations}

Based on the conclusion of this study, it recommends as follows:

1. Employers should recognize what they want from their objectives and reward employees based on that.

2. Those employees who purposely or inadvertently emit positive behaviors in line and useful to the realization of organizational goals should be encouraged through positive rewards for increased effective performance.

3. The employees who constantly emits negative behaviors should be discouraged through negative reward.

4. Organizations should constantly review their objectives to make sure that they are in agreement with the rewards they give to employees.

5. Organizations in Nigeria should practically apply for full evaluation of its potentials and success stories.

\section{References}

Agbionu (2006) Human Resource Management and Industrial Relations, Awka, Unique Press.

Agbionu (2008) Human Resource Management and Industrial Relations in Nigeria, Awka Unique Press.

Agbionu CU, Ogadi PN and Agbasi OE (2013) Job Satisfaction and Organizational Effectiveness. Humberside Journal of Social Sciences 2(1): 57-63.

Agbionu CU, Ogadi PN and Agbasi OE (2014) Approaches To Organizational Effectiveness And The Success Of
Entrepreneurial Organizations In Eastern Nigeria. British Journal of Advance Academic Research 3(1): 67-73.

Agbionu CU and Agbionu EO (2013) Poverty Alleviation in Nigeria; Deeper Insight into Nigeria's Public Administration, Blooington, Author House LLC.

Agbionu CU, Emejulu G and Adigwe PK (2013) Agricultural Transformation and Poverty Alleviation in Nigeria: A Correlational Evaluation, British Journal of Advanced Academic Research 2(1): 117-125.

Bage (2012) Review of Micheal LeBoeuf's Greatest Management Principle, www. Wikipedia.wordpress.com.

Banjoko S (1996) Human Resource Management in Nigeria: An Expository Approach, Lagos, Saban Publishers, First Edition.

Banjoko S (2006) Human Resource Management in Nigeria: An Expository Approach, Lagos, Saban Publishers, Second Edition.

Berge (1972) The Greatest Management Principle in the World: A Critical Survey of Contemporary Fiction: Online.

Budgle B (2013) Thoughts on The Greatest Management Principles in the World Online.

Bugle (2013) Review of Micheal LeBoeuf's Greatest Management Principle, www.wikipedia.wordpress.com.

Fashoyin T (2005) Management in Africa Lagos Organization Review (LOR) 1(1)

Federal Government of Nigeria (2005) Performance Management Review 3(1).

Goodluck Jonathan (2014) Being a Paper Presented on Nigerian Democracy Day, $29^{\text {th }}$ May.

Ibidapo-Obe O (2005) Innovative Paradigm for Best Practices in the Nigerian University System, Lagos Organization Review (LOR) Vol. 1 No 1 June-August.

LeBoeuf M (2009) Greatest Management Principle in the World, New Orleans.

National Planning Committee (2005) National Economic Empowerment and Development Strategy, CBN.

Obasajo (2003) in Nnamani 2003, A Paper Presented on the State of Nigerian Economy.

Thomas AB (2003) Controversies in Management Issues, Debates, Answers. 2nd edition, London, Routledge. 